\title{
KARAKTERISTIK SENSORI TEMPE KACANG TUNGGAK HITAM DAN TEMPE KEDELAI
}

\section{Sensory Characteristics of Black Cowpea and Soybean Tempeh}

\author{
Hyldegardis Naisali ${ }^{1,2 *}$, Siti Narsito Wulan ${ }^{1}$ \\ 1) Jurusan Teknologi Hasil Pertanian, FTP Universitas Brawijaya \\ Jl. Veteran, Malang 65145 \\ 2) Jurusan Agroteknologi, Faperta Universitas Timor \\ Sasi, Kefamenanu 85613 \\ *Penulis Korespondensi, Email: hylde3naisali@gmail.com
}

\begin{abstract}
ABSTRAK
Kacang tunggak hitam merupakan salah satu potensi lokal Pulau Timor-Nusa Tenggara Timur, biasanya dimasak dengan jagung bose. Komposisi gizi kacang tunggak sebagai sumber protein memang lebih rendah (14-15\%) dibandingkan kedelai $(28-30 \%)$ namun masih potensial dibuat menjadi tempe. Tempe adalah hasil fermentasi biji kedelai oleh Rhizopus sp. Pada penelitian ini, tempe kacang tunggak dibuat dengan mengamati 2 faktor perlakuan yaitu konsentrasi ragi 1\%, 1.5\%, 2\% dan lama waktu fermentasi 24 jam, 36 jam, 48 jam. Kombinasi perlakuan terbaik (sedang diajukan paten) dipilih, disiapkan dengan dipotong $3 \times 3 \mathrm{~cm}$ lalu digoreng dan dilakukan uji organoletik dibandingkan dengan tempe kedelai sebagai kontrol. Tujuan penelitian ini adalah mengetahui tingkat kesukaan panelis pada skala hedonik 1-5 (tidak suka-sangat suka) dengan atribut sensori warna, aroma, tekstur dan rasa. Hasil uji sensori menunjukkan panelis lebih menyukai tempe kedelai (rerata 4.5 skala hedonik) dibandingkan tempe kacang tunggak hitam (rerata 3.67).
\end{abstract}

Kata kunci: Kacang tunggak hitam, Komparasi, Sensori, Tempe

\begin{abstract}
Cowpeas are usually cooked with jagung bose, traditional food in East Nusa Tenggara. Protein content of cowpea (14-15\%) is less than those in soybeans (28-30\%) but still a potential source. In this study, tempeh was made from cowpeas instead of soybeans. Two factors were observed namely the concentration of tempeh starter (1\%, 1.5\% and $2 \%)$ and fermentation time (12, 24, 36 hours). The best cowpea tempeh was selected, cut into $3 \times 3 \mathrm{~cm}$ dimension, fried and sensory evaluated. The best treatment combination was not revealed here due to patent registration issue. The main purpose of the study was to determine the level of consumer acceptance of cowpea tempeh compared to soybean tempeh by using a hedonic scale method from 1-5 (dislike to very like) with sensory attributes including color, aroma, texture, and taste. Soybean tempeh (on average 4.5 hedonic scale) was preferred more than cowpea tempeh (on average 3.67).
\end{abstract}

Keywords: Black Cowpea, Compared, Sensory, Tempeh

\section{PENDAHULUAN}

Kacang tunggak hitam (Vigna unguiculata, (L). Walp) adalah salah satu potensi lokal Pulau Timor-Nusa Tenggara Timur (NTT). Ketersediaan benih sangat melimpah namun pemanfaatan tanaman pangan ini belum sepenuhnya dieksplorasi. Kendala pemanfaatan kacang tunggak hitam disebabkan karena kulit dan tekstur biji yang keras sulit dilepaskan dibandingkan dengan kedelai. Selain tekstur yang keras, bau langu yang tidak sedap merupakan salah satu faktor yang menyebabkan kacang tunggak hitam kurang disukai. Hal ini 
disebabkan adanya enzim lipoksigenase yang secara alami ada dalam biji kacang sehingga menyebabkan bau langu. Menurut Ginting et al., (2009), pada saat biji pecah karena proses pengupasan, enzim lipoksigenase akan aktif karena adanya kontak dengan oksigen. Warna kacang yang menyebabkan warna akhir produk kurang menarik.

Biji legum biasanya dicampurkan dengan jagung sebagai makan pokok secara turun temurun di Pulau Timor (Puspita et al., 2017). Menurut Gatson et al (2006), proses memasak yang lama menyebabkan menurunnya nilai gizi. Salah satu cara menjaga dan meningkatkan kandungan protein kacang tunggak adalah dengan membuat tempe. Tempe adalah makanan sumber protein tinggi hasil fermentasi kacang menggunakan Rhizopus sp. yang mudah dijangkau oleh seluruh lapisan masyarakat dengan harga yang murah. Secara umum, masyarakat Indonesia mengkonsumsi tempe kedelai sebagai lauk atau cemilan, dan jarang atau tidak pernah mengkonsumsi tempe kacang tunggak hitam. Sumber bahan pokok dalam kedelai diantaranya asam amino esensial, protein, vitamin dan mineral. Tempe mengandung berbagai macam kandungan yang mempunyai nilai obat, seperti antioksidan pencegah penyakit degeneratif dan antibiotik untuk menyembuhkan infeksi.

Tempe dengan bahan baku kacang kedelai sangat disukai masyarakat Indonesia selama ini. Selain kedelai sebagai bahan baku tempe, menurut Haliza et al., (2016) tempe kacang tunggak dapat diterima dan disukai konsumen pada uji preferensi terhadap responden yang berasal dari pulau yang berbeda. Menurut Tarwendah (2017), untuk mengetahui kualitas produk yang dapat memenuhi harapan yaitu dengan cara melakukan studi komparasi dengan produk kompetitor. Oleh karena itu, tingkat penerimaan tempe kacang tunggak dibandingkan dengan tempe kedelai perlu dilakukan. Dengan demikian, penelitian ini bertujuan untuk mengetahui tingkat penerimaan panelis terhadap tempe kacang tunggak dibandingkan tempe kedelai.

\section{BAHAN DAN METODE}

Penelitian ini dilakukan di Laboratorium Uji Ilmu Sensori dan Pangan Terapan, Jurusan Teknologi Hasil Pertanian Brawijaya. Penelitian dilakukan pada bulan April 2019.

\section{Bahan}

Sampel kacang tunggak hitam berasal dari petani Desa Letneo Selatan, Kecamatan Insana Barat, Kabupaten Timor Tengah Utara (TTU), Propinsi NTT. Sedangkan tempe kedelai berasal dari UKM "Tempe Sanan" yang difermentasi menggunakan ragi komersial (RAPRIMA), ragi yang dibeli di koperasi UKM Tempe Sanan, Minyak Goreng

Alat

kue.

Baskom, panci, saringan, pengaduk, plastik pembungkus, tusuk gigi, nampan, kertas

\section{Desain Penelitian}

Desain penelitian ini menggunakan satu faktor perlakuan yaitu tempe kacang tunggak hitam dan tempe kedelai yang sama-sama digoreng. Analisis data secara statistik menggunakan uji paired T-test $\alpha=0.05$ menggunakan software Minitab 17 .

\section{Tahapan Penelitian}

Tahapan penelitian ini meliputi pembuatan tempe kacang tunggak hitam, penggorengan dan evaluasi sensori. Metode pembuatan tempe dilakukan sesuai metode (Egounlety, 2003) dengan sedikit modifikasi. Kacang tunggak hitam disortasi, dicuci dan direndam dalam air mendidih semalaman. Kacang kemudian dikupas kulit dengan alat pengupas kulit, setelah itu dipisahkan kulit. Kacang kupas kulit direndam selama 48 jam hingga berbusa. Kemudian, kacang dicuci dan direbus selama \pm 20 menit dengan tujuan menginaktifkan bakteri kontaminan yang ada selama proses perendaman selanjutnya 
dikeringanginkan. Setelah dingin dan kering kacang tunggak hitam ditaburi ragi (RAPRIMA) dan dicampur hingga merata kemudian dibungkus dengan plastik berlubang dan direkatkan. Kemudian, bungkusan kacang dengan komposisi ragi (1\%, $1.5 \%$, atau $2 \%)$ dibiarkan dalam suhu ruang $\pm 27-30^{\circ}$ selama (12, 24 atau 36 jam) hingga kacang terlihat putih oleh rajutan miselia. Kombinasi perlakuan terbaik tempe kacang tunggak dilakukan uji organoleptik dengan tempe kedelai sebagai kontrol. Kombinasi perlakuan terbaik tempe kacang tunggak sedang diajukan paten, sehingga tidak disampaikan seluruhnya. Tempe kacang tunggak kemudian dipotong dengan ukuran sama $(3 \mathrm{~cm} \times 3 \mathrm{~cm})$ digoreng dalam minyak panas sekitar 3 menit hingga berwarna sebelum disajikan kepada panelis. Perlakuan yang sama diberikan pada tempe kedelai sebagai kontrol.

\section{Metode}

Metode hedonis, dengan skala preferensi berkisar antara 1- 5 (1:sangat tidak suka; 2:tidak suka; 3:netral; 4:suka; 5:sangat suka) dengan menggunakan 30 panelis yang tidak terlatih.

\section{Prosedur Analisis}

Masing-masing panelis diberi 2 tempe goreng $(3 \mathrm{~cm} \times 3 \mathrm{~cm})$ yang dihasilkan dari 2 jenis tempe yaitu tempe kacang tunggak hitam dan tempe kedelai. Panelis diminta untuk memberi nilai berdasarkan skala hedonis. Atribut sensori yang diuji berupa warna, aroma, tekstur dan rasa selanjutnya dilakukan uji paired $T$-test dengan menggunakan minitab 17 . Tingkat signifikansi ditetapkan pada level 0.05 .

\section{HASIL DAN PEMBAHASAN}

\section{Warna}

Selera seseorang terhadap suatu produk makanan sangat dipengaruhi dari warna dimana warna yang menarik dan terlihat alami yang disukai. Komparasi preferensi panelis terhadap warna tempe kacang tunggak hitam (KNT) dan tempe kedelai (TKD) yang ditunjukkan pada Table 1 dan data warna tempe ditunjukkan pada Gambar 1. Rata-rata preferensi panelis untuk KNT adalah 3.67 sedangkan TKD adalah 4.50 hal ini disebabkan karena kacang tunggak keras, warna hitam sehingga tempe kacang tunggak hitam sedikit tidak menarik. Pembentukan miselium menentukan warna tempe, miselium padat akan menutupi permukaan kacang sehingga menghasilkan tempe yang akan terlihat putih. Menurut Winanti et al. ( 2014), tempe yang berwarna putih adalah tempe yang baik. Panelis cenderung menyukai warna yang dihasilkan oleh tempe kedelai dibandingkan dengan tempe kacang tunggak. Hasil perbandingan menggunakan paired $t$-Test antara kacang tunggak dan tempe kedelai diperoleh nilai $p$ value $=0.000$. Perbedaan yang signifikan ditunjukkan bahwa warna kedua produk memiliki yaitu nilai $p<0.05$. Menurut panelis, tempe kacang tunggak hitam memilki warna yang tidak disukai. Warna tempe kacang tunggak hitam ini memiliki bintik-bintik hitam yang memberikan kesan menyimpang atau warna yang tidak sedap dipandang. Warna ini berasal dari pigmen hitam pada bagian kulit kacang sehingga menghasilkan warna tempe yang berbeda dengan tempe kedelai pada umumnya. Menurut Sarwono (2006), warna putih adalah warna tempe yang baik, membentuk padatan yang terikat oleh miselium sehingga bila dipotong kepingan kedelai tampak rata, sama besar dan rapat. 


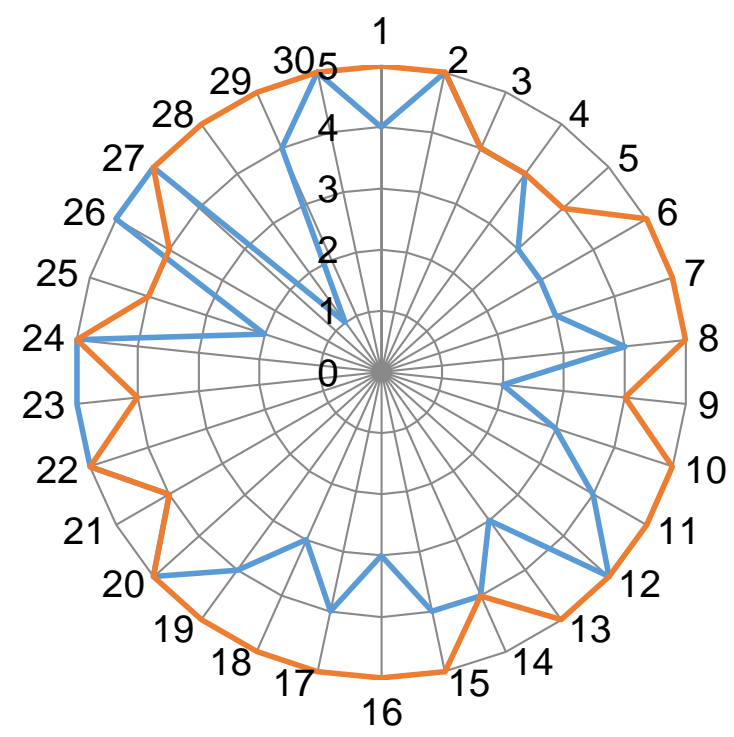

Tempe Kacang
Tunggak Hitam
Tempe Kedelai

Gambar 1. Preferensi 30 panelis pada parameter warna

Tabel 1. Hasil Uji Sensori Tempe Goreng dengan bahan baku berbeda

\begin{tabular}{ccccc}
\hline & \multicolumn{4}{c}{ Sifat sensori ${ }^{*}$ ) } \\
\cline { 2 - 5 } Jenis Tempe & Warna & Aroma & Tekstur & Rasa \\
\hline Tempe Kacang Tunggak Hitam & $3.83 \pm 1.04$ & $3.97 \pm 0.87$ & $4.03 \pm 0.84$ & $3.70 \pm 1.06$ \\
Tempe kedelai & $4.50 \pm 0.67$ & $4.47 \pm 0.72$ & $4.57 \pm 0.56$ & $4.70 \pm 0.46$ \\
Nilai P & 0.000 & 0.030 & 0.003 & 0.003 \\
\hline
\end{tabular}

Catatan: $\left.{ }^{\star}\right) n=30$ panelis

\section{Aroma}

Pengujian aroma dalam industri makanan sangat penting karena memberikan hasil produk yang terkait dengan cepat dan apakah suatu produk diterima atau tidak (Nout dan Kiers, 2005). Proses fermentasi dalam tempe akan mempengaruhi terhadap aroma tempe. Preferensi semua data parameter aroma yang ditunjukkan pada Gambar 2, sedangkan perbandingan preferensi aroma KNT dan TKD ditunjukkan pada Tabel 1. Rata-rata preferensi panelis untuk KNT adalah 3.97 sementara TKD adalah 4.47. Panelis cenderung lebih menyukai aroma yang dihasilkan tempe kedelai dibandingkan dengan tempe kacang tunggak hitam. Hasil perbandingan menggunakan paired T-test antara KNT dan TKD diperoleh nilai pvalue $=0.030$. Menurut panelis nilai $p<0.05$ menunjukkan bahwa aroma kedua produk mempunyai perbedaan yang signifikan. Bahan baku yang digunakan dalam proses fermentasi mempengaruhi aroma tempe. Penelitian yang dilakukan Winanti et al. (2014) menyebutkan tempe segar memiliki aroma lembut khas tempe dan tidak menyengat. Astawan et al. (2015) menambahkan aroma lembut tempe segar berasal dari aroma miselium kapang bercampur aroma lezat asam amino bebas dan aroma lembut yang ditimbulkan jamur akan berubah menjadi tajam akibat semakin lama waktu fermentasi berlangsung akan menguraikan lemak dan terjadi pelepasan amonia. 


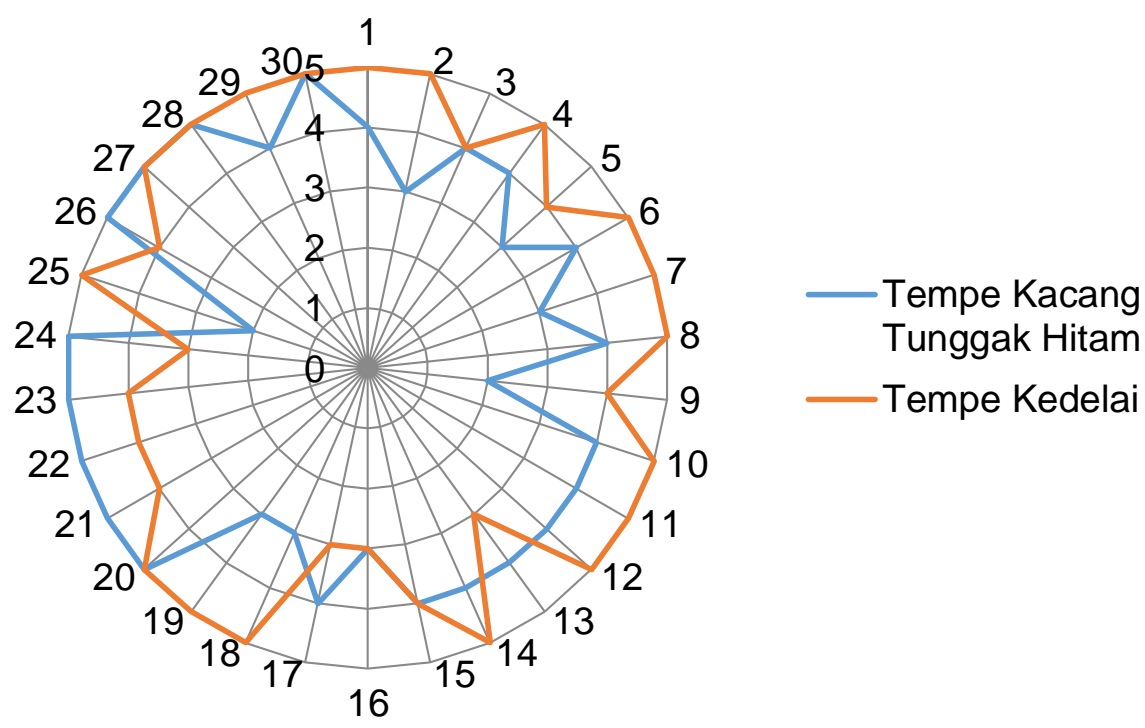

Gambar 2. Preferensi 30 panelis pada parameter aroma

\section{Tekstur}

Preferensi panelis pada tekstur KNT dan TKD ditunjukkan pada Tabel 1, sedangkan semua data preferensi tekstur ditunjukkan pada Gambar 3.

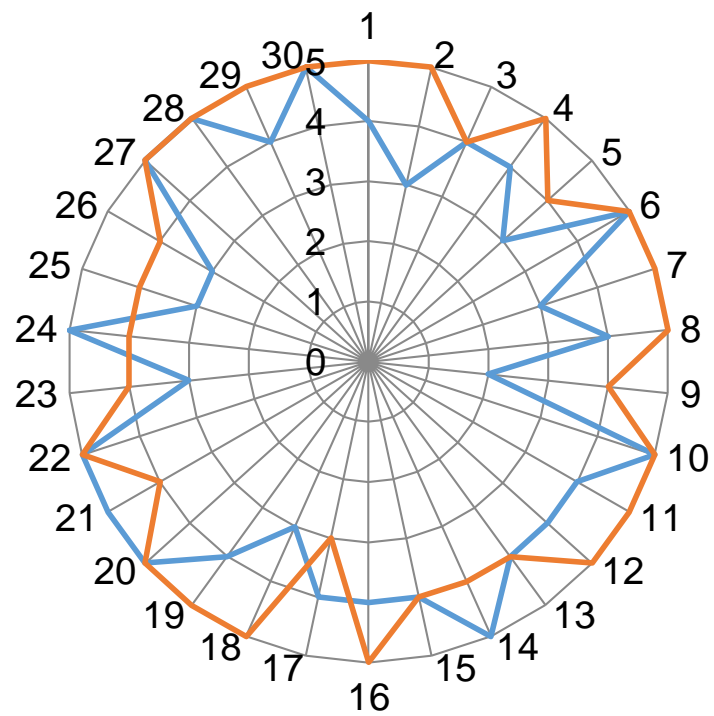

- Tempe Kacang Tunggak Hitam

— Tempe Kedelai

Gambar 3. Preferensi 30 panelis pada parameter tekstur

Rata-rata preferensi panelis untuk KNT adalah 4.03 sedangkan TKD adalah 4.57. Tekstur yang padat disebabkan oleh miselia yang menyatukan biji kacang. Menurut Rahardjo et al. (2019), miselium kapang akan membentuk padatan kompak sehingga menghasilkan tempe yang berkualitas. Mujianto (2013) menambahkan semakin baik tekstur tempe jika semakin banyak miselium kapang yang tumbuh pada tempe. Miselium kapang akan meningkatkan kerapatan masa tempe satu sama lain sehingga mengurangi rongga udara di dalamnya dan membentuk suatu massa yang kompak. Hasil komparatif menggunakan paired $T$-test antara KNT dan TKD diperoleh nilai $\mathrm{p}$ value $=0.003$. Nilai $\mathrm{p}<0.05$ menunjukkan bahwa kedua produk mempunyai perbedaan yang signifikan pada parameter tekstur menurut panelis. Perbedaan ini disebabkan karena tekstur kacang tunggak hitam yang digunakan dalam 
pembuatan tempe, memiliki kulit dan biji yang agak keras sehingga mempengaruhi hasil akhir produk tempe, sedangkan tekstur tempe kedelai lebih lunak ketika dikunyah.

\section{Rasa}

Rasa tempe pada umumnya gurih hal ini karena ada protein dan kandungan lemak yang tinggi yang kemudian dihidrolisis oleh kapang menjadi senyawa yang lebih sederhana.Tingkat kesukaan panelis terhadap rasa KNT dan TKD ditunjukkan pada Tabel 1, dan semua data ditunjukkan pada Gambar 4. Rata-rata preferensi panelis untuk KNT adalah 3.70 dan TKD adalah 4.70. Menurut Istiqomah et al. (2018) dalam proses fermentasi jamur menggunakan protein, lemak, dan karbohidrat dalam bahan sehingga menghasilkan rasa khas tempe. Hal ini membuat tempe lebih gurih ketika digoreng dibandingkan tempe lainnya. Hasil komparasi menggunakan paired $T$-test antara KNT dan TKD diperoleh nilai $p=0.003$. Nilai $p$ value $<0.05$ menunjukkan bahwa kedua produk memiliki perbedaan yang signifikan pada parameter rasa menurut panelis. Rasa agak pahit dalam tempe kacang tunggak hitam menyebabkan agak disukai oleh panelis. Rasa pahit berasal dari kandungan asam amino lisin yang terdapat dalam kacang tunggak hitam. Johson dan Peterson menyebutkan bahwa asamasam amino seperti lisin, fenilalanin, prolin, arginine dan valin merupakan penyebab rasa pahit. Menurut Kurniawati (2012), asam amino lisin adalah asam amino yang memiliki rasa paling pahit dibandingkan asam amino penyebab rasa pahit lainnya.

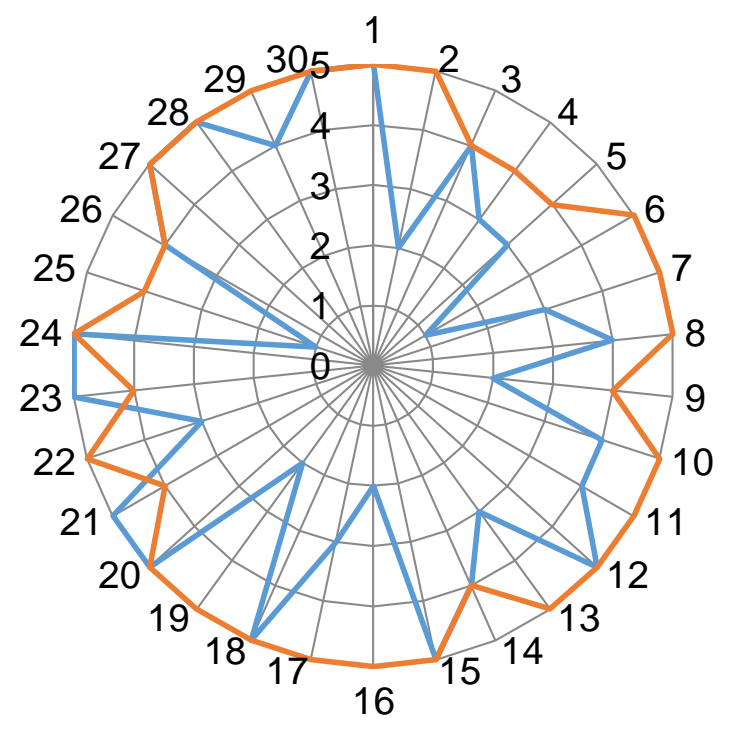

- Tempe Kacang Tunggak Hitam

— Tempe Kedelai

Gambar 3. Preferensi 30 panelis pada parameter tekstur

\section{SIMPULAN}

Berdasarkan penilaian panelis terhadap sampel KNT dan TKD dapat dilihat bahwa tempe kedelai (TKD) adalah yang lebih disukai panelis dibandingkan KNT (tempe kacang tunggak hitam). Hasil komparasi semua parameter (warna, aroma, tekstur dan rasa) menunjukkan perbedaan signifikan antara KNT dibandingkan TKD.

\section{UCAPAN TERIMA KASIH}

Puji syukur penulis panjatkan Kepada Tuhan Yesus atas segala rahmat dan kemudahan yang diberikan-Nya. Ucapan terima kasih penulis sampaikan kepada pembimbing Dr. Siti Narsito Wulan, STP., MP yang telah memberi masukan sehingga penelitian ini dapat 
terlaksana hingga akhir, suami dan anak-anak, orang tua, keluarga, teman-teman serta semua pihak yang telah mendukung penyusunan jurnal ilmiah ini.

\section{DAFTAR PUSTAKA}

Astawan, M., Wresdiyati, T. and Sirait, J. 2015. Pengaruh Konsumsi Tempe Kedelai Grobogan Terhadap Profil Serum, Hematologi Dan Antioksidan Tikus. Jurnal Teknologi dan Industri Pangan, 26(2), pp. 155-162. doi: 10.6066/jtip.2015.26.2.155.

Egounlety, M. 2003. Effect of soaking, dehulling, cooking and fermentation with Rhizopus oligosporus. 56, pp. 249-254.

Gatson, J. W. et al. 2006. Bacillus tequilensis sp. nov., isolated from a 2000-year-old Mexican shaft-tomb, is closely related to Bacillus subtilis. International Journal of Systematic and Evolutionary Microbiology, 56(7), pp. 1475-1484. doi: 10.1099/ijs.0.63946-0.

Ginting, E., Antarlina, S. S. and Widowati, S. 2009. Variates Unggul Kedelai Untuk Bahan Baku Industri Pangan (Soybean Superior Varieties for Raw Materials Food Industry). Jurnal Litbang Pertanian, 28(3), pp. 79-87.

Haliza W., Purwani E.Y. dan Thahir R. 2016. Pemanfaatan kacang-kacangan lokal sebagai substitusi bahan baku tempe dan tahu. Buletin Teknologi Pasca Panen, 3(1), pp. 1-8

Istiqomah, Nurrahman and Nurhidajah. 2018. Sifat Sensoris Tempe Kedelai Hitam Dengan Variasi Penambahan Kecambah Dan Lama Inkubasi. Jurnal Pangan dan Gizi, 8(2), pp. 70-81.

Kurniawati. 2012. Pengaruh Substitusi Tepung Terigu Dengan Tepung Tempe Dan Tepung Ubi Jalar Kuning Terhadap Kadar Protein, Kadar B-Karoten, Dan Mutu Organoleptik Roti Manis. Journal Of Nutrition College, 1 (Http://Ejournal-S1.Undip.Ac.Id/Index.Php/Jnc.).

Mujianto. 2013. Analisis Faktor Yang Mempengaruhi Proses Produksi Tempe Produk UMKM di Kabupaten Sidoharjo. Jurnal REKA Agroindustri Media Teknologi dan Menejemen Agroindustri, I(1).

Nout, M. J. R. and Kiers, J. L. 2005. Tempe fermentation, innovation and functionality: update into the third millenium. Journal of Applied Microbiology, 98(4), pp. 789-805. doi: 10.1111/j.1365-2672.2004.02471.x.

Puspita, D., Palimbong, S., Toy, B., dan Notosoedarmo, S. 2017. Identifikasi legum lokal di pulau timor yang berpotensi dalam pengembangan inovasi pangan lokal. Pengembangan Sumber Daya Perdesaan Dan Kearifan Lokal Berkelanjutan VI, (November), 324-335.

Rahardjo L.J., Asrul B. and Annis C.A. 2019. Pengaruh Kombinasi Kacang Kedelai (Glycine Max) Dan Kacang Tunggak (Vigna Unguiculata (L) Walp.) Yang Diperkaya Biji Nangka (Artocarpus Heterophyllus) Terhadap Daya Terima Dan Kadar Protein Snack Bar. Amerta Nutrition, 3(1), pp. 71-77. doi: 10.2473/amnt.v3i1.2019.71-77.

Sarwono. 2006. Membuat Tempe dan Oncom. Edited by Penebar Swadaya. Jakarta.

Tarwendah I. P. 2015. Studi Komparasi atribut Sensori dan Kesadaran Merek Produk Pangan. Jurnal Pangan dan Agroindustri, 5(2), pp. 66-73.

Winanti, Bintari dan Mustikaningtyas. 2014. Higienitas Produk Tempe berdasarkan Perbedaan Metode Inokulasi. Unnes Jurnal of Life Science, 3(1), pp. 39-46. 